EGALITA, Jurnal Kesetaraan dan Keadilan Gender, Pusat Studi Gender (PSG) Universitas Islam Negeri Maulana Malik Ibrahim Malang. Copyright @ 2009. Vol. IV Nomor 2 Tahun 2009 : 217 - 229

\title{
DOMESTIKASI PERAN SUAMI DALAM KELUARGA
}

\author{
Muassomah \\ Jurusan Bahasa Arab Fakultas HumBud UIN Maliki Malang \\ Telepon: 081334845570 \\ E-mail:muas_somah@yahoo.com
}

\begin{abstract}
Abstrak
The fundamental difference between men and women is seen in terms of biology and anatomy. Viewed from the aspect of biological male has advantages compared with women. Men have a sturdy and strong muscle, while women are more delicate. Anatomically, men do not have a uterus for pregnancy, while women have a uterus so that it is possible to conceive and bear children. With the difference that the role of men and women also differ. Some argue that the role of men is to earn a living for his family, while the task of women is pregnant, giving birth and raising children, as well as housewives. But this role is changing. The factors that cause changes in the role of the husband's public role to the domestic role is due to economic.
\end{abstract}

Perbedaan yang mendasar antara pria dan wanita terlihat dari segi biologis dan anatomi. Dilihat dari segi biologis pria memiliki kelebihan dibandingkan dengan wanita. Pria memiliki otot yang kekar dan kuat sedangkan wanita lebih lembut. Secara anatomis, pria tidak memiliki rahim untuk mengandung, sedangkan wanita memiliki rahim sehingga dimungkinkan untuk mengandung dan melahirkan anak. Dengan perbedaan itulah peran pria dan wanita juga berbeda. Ada yang berpendapat bahwa peran pria 


\section{Muassomah}

adalah mencari nafkah untuk keluarganya, sedangkan tugas wanita adalah mengandung, melahirkan dan membesarkan anak, serta sebagai ibu rumah tangga. Namun peran ini mengalami perubahan. Adapun faktor yang menyebabkan terjadinya perubahan peran suami dari peran publik ke peran domestik adalah karena faktor ekonomi.

Keywords: Domestik, Peran suami, Keluarga

\section{Pendahuluan}

Perubahan sosial budaya yang sedemikian pesat yang merupakan imbas konsekwensi mutlak dari proses rotasi pembangunan yang cepat atau dipercepat demi pertimbangan-pertimbangan tertentu sebagaimana yang terjadi di Indonesia telah mendorong peran wanita tidak lagi hanya berputar di sekitar kegiatan kerumahtanggaan saja, tetapi lebih kepada terbukanya kesempatan yang seluas-luasnya bagi mereka untuk memasuki bidang-bidang kegiatan di sektor publik, yaitu sebagai wanita yang berkecimpung pada pekerjaan diluar rumah, baik sebagai wanita karier maupun sebagai tenaga-tenaga profesional dalam berbagai bidang yang ada. Dengan demikian terjadilah perubahan dan kedudukan peran wanita. Sehubungan dengan domestikasi peran suami dalam keluarga dan peranan wanita dalam kerja yang mencerminkan statusnya sebagai pencari nafkah, Sajogyo (1989) mengemukakan bahwa apabila keluarga sudah tidak mungkin untuk memenuhi keperluan anggota keluarganya, maka salah satu anggota keluarga itu diberi kesempatan bekerja mencari nafkah. Kondisi demikian akan mengenai wanita. Dalam kondisi tertentu, wanita harus terjun langsung ke dunia kerja demi keamanan keluarganya.

\section{Gender dalam Perspektif Sosiologis}

Gender menurut Karrie Layun Rampan dan Titiek W.S. Ed. (2000:2) adalah suatu konsep yang menunjuk pada suatu sistem peranan dan hubungannya antara perempuan dan laki-laki yang tidak diterminasikan oleh perbedaan biologis, namun lebih dikarenakan oleh lingkungan sosial, politik dan ekonomi. Sedangkan perspektif gender adalah sustu konsep yang dipergunakan untuk membedakan segala sesuatu yang merupakan produk sosio budaya dalam bentuk kesepakatan dan fleksibilitas sosial yang dapat ditransformasikan. Analisis peran gender merupakan pengkajian sistematis tentang peranan, hubungan dan proses yang difokuskan pada 
ketidaksetaraan dalam kekuasaan, kekayaan dan bebas kerja antara perempuan dan lelaki dalam keseluruan masyarakat.

Dari sudut pandang sosiologis, pembedaan peran antara perempuan dan laki-laki merupakan implikasi dari konstruksi sosial dalam lingkungan yang patriarkhis (male oriented) di mana terdapat hal-hal normatif atau yang semestinya dan sepatutnya dikerjakan perempuan dan laki-laki. Situasi ini tentunya dapat berubah dan diubah sesuai dengan kondisi dan tuntutan zaman. Membedakan hubungan antara laki-laki dan perempuan dari visi biologis (yaitu perempuan memiliki kodratnya untuk mampu menstruasi, mengandung dan menyususi) dan pembelajaran sosial, merupakan sesuatu yang sulit dicari garis pemisahnya secara jelas karena bersifat saling melengkapi. Untuk memantapkan dan menyokong pengintegrasian wawasan gender dalam pembangunan, saat ini telah dikembangkan suatu teknik untuk perencanaan pembangunan dengan basis sumber daya manusia dan aspek pola hubungan sosial antara laki-laki dan perempuan sebagai pelaku pembangunan dengan teknis Analisis Gender.

Masih banyak ditemukan indikasi ketidakadilan terhadap perempuan sebagai akibat bias gender yang masih tetap berakar di masyarakat. Ketimpangan ini dianggap perlu diatasi melalui pendekatan gender berwawasan kemitraan (kemitrasejajaran gender). Wawasan kemitrasejajaran yang harmonis merupakan cerminan kondisi dinamis antara perempuan dan laki-laki dalam konteks kesamaan hak, kewajiban dan kedudukan serta kesempatan untuk mengakses berbagai aset ekonomi bersumber pada Pancasila sebagai landasan idiil, UUD 1945 sebagai landasan konstitusional dan GBHN sebagai landasan operasional.

Ketidakadilan gender ini sering kali dijumpai di tengah-tengah kesibukan kaum perempuan yang sudah berkeluarga, di mana sering kali dikondisikan dalam keterpurukan sebagai pekerja domestik di rumah. Padahal sebenarnya banyak dari mereka yang hati dan dirinya terdorong untuk maju, tetapi pada waktu yang bersamaan, mereka juga banyak yang menahan gerak itu. Ketidakmampuan kaum perempuan mempertahankan citra diri yang positif dan utuh sebagai pekerja yang feminim merintangi aspirasi yang paling diidam-idamkan. Bahkan, seluruh hubungan perempuan dengan pekerjaannya bersifat reaktif. Wanita bekerja bila pria "mengizinkan" mereka untuk bekerja "yang tentu saja, artinya adalah, bila pria membutuhkan mereka untuk bekerja. Karena pria membutuhkan wanita bekerja, maka isteri yang bekerja juga diizinkan oleh masyarakat. Wanita merasa bahwa kebebasan baru untuk bekerja dan juga menjadi isteri itu tidak datang dari 


\section{Muassomah}

diri mereka sendiri, mereka hanya mendapatkan izin.

Gender dipakai untuk pembagian struktur sosial berdasarkan jenis kelamin. Sedang seks (jenis kelamin), dibedakan untuk membedakan pria dan wanita secara biologis dan anatomis. pengertian jenis kelamin merupakan pensifatan atau pembagian dua jenis kelamin manusia yang ditentukan secara biologis yang melekat pada jenis kelamin tertentu. Misalnya, pria adalah manusia yang memiliki atau bersifat pada daftar berikut: memiliki penis dan menghasilkan sperma. Sedangkan kaum wanita adalah memiliki alat vagina, alat reproduksi telur dan alat untuk menyusui. Alat tersebut secara biologis melekat pada manusia jenis pria dan wanita. Secara permanen tidak berubah dan merupakan ketentuan biologis atau sering dikatakan sebagai ketentuan Tuhan atau kodrat.

Dari analisis peran gender di atas, dapat diketahui bahwa konsep gender tidak mengacu pada perbedaan biologis antara perempuan dan laki-laki, melainkan pada perbedaan psikologis, sosial dan budaya yang dikaitkan masyarakat antara laki-laki dan perempuan, karena gender tidak bersifat biologis melainkan dikonstruksi sosial. Proses sosialisasi yang membentuk persepsi diri dan aspirasi ini dalam sosiologi biasanya diistilahkan dengan soaialisasi gender, yang berawal dari keluarga. Melalui proses pembelajaran gender, seseorang mempelajari peran gender yang oleh masyarakat dianggap sesuai dengan jenis kelaminnya.

\section{Peran Pria dan Wanita dalam Keluarga}

Secara fisik pria dan wanita memiliki perbedaan. Perbedaan yang mendasar terlihat dari segi biologis dan anatomi. Dilihat dari segi biologis pria memiliki kelebihan dibandingkan dengan wanita. Pria memiliki otot yang kekar dan kuat sedangkan wanita lebih lembut. Secara anatomis, pria tidak memiliki rahim untuk mengandung, sedangkan wanita memiliki rahim sehingga dimungkinkan untuk mengandung dan melahirkan anak.

Menurut Teori Nature, peran wanita adalah mengurus rumah tangga, yakni melahirkan anak dan membesarkannya dalam lingkungan rumah tangga, memasak dan memberikan perhatian kepada suami agar dapat terjalin kehidupan rumah tangga yang tentram dan sejahtera, sedangkan pria berperan di luar rumah tangga mencari nafkah untuk menghidupi keluarga. Pembagian ini didasarkan atas perbedaan seks yang diatur oleh alam, secara alamiah, pria diberi kekuatan otot untuk bekerja mencari nafkah, di satu sisi, pria tidak memiliki kemampuan mengandung dan melahirkan anak karena memang tidak memiliki organ tubuh yang memungkinkan 
untuk mengandung dan melahirkan anak, sedangkan wanita memiliki organ tubuh yang memungkinkan untuk mengandung dan melahirkan anak. Berdasarkan hal itu, maka tugas mengasuh dan merawat anak menjadi tanggung jawab wanita, Karena tugas tersebut lebih banyak dilakukan di dalam rumah tangga, maka secara langsung wanita juga memiliki tanggung jawab untuk mengurus rumah tangga.

Sejalan dengan Teori Nature, Teori Fungsional juga berpandangan bahwa wanita harus tinggal di dalam rumah tangga karena hal ini merupakan pembagian yang paling baik dan berguna bagi keuntungan masyarakat secara keseluruhan. Talcot Parsons juga menyatakan bahwa pekerjaan wanita adalah mengerjakan pekerjaan-pekerjaan rumah tangga. Menurutnya, dengan diadakan pembagian yang jelas akan dapat dicegah kemungkinan terjadinya persaingan antara suami dan isteri (Parsons, 1972:172). Dengan pembagian kerja seperti ini maka jelaslah bahwa suami mengembangkan kariernya di luar rumah dan isteri berada di rumah. Isteri boleh bekerja di luar rumah, tapi hendaknya itu bukan merupakan kariernya, kalau tidak, pasti akan menimbulkan persaingan antara suami dan isteri yang pada akhirnya akan merusak keserasian hubungan dalam perkawinan.

Menurut Teori Marx, pembagian secara seksual bisa bertahan lama merupakan sesuatu yang wajar, melainkan karena pria masih tetap berkuasa. Engel menyatakan bahwa sebelum pria mengambil kekuasaan, pekerjaan di dalam rumah dan di luar rumah sama saja. Keduanya tidak menjadikan yang bekerja di luar rumah lebih kaya dibandingkan yang bekerja di dalam rumah. Ketimpangan terjadi pada saat pekerjaan di luar rumah memberikan imbalan kekayaan yang tidak seimbang dengan pekerjaan di dalam rumah tangga. Pada kondisi seperti inilah laki-laki menjadi lebih kuat posisinya di da-lam masyarakat dan wanita menjadi lemah.

Sifat gender adalah Cultural spesific dan dinamis, artinya dapat bervariasi dari lingkungan sosio-kultural ke sosio-kultural yang lain, hal itu juga dapat mengalami perubahan seiring dengan perubahan kultur masyarakat yang bersangkutan.

Masih dalam kaitanya dengan pembagian peran pria dan wanita dalam keluarga, Djalaluddin Rahmat (1992) mengemukakan adanya tiga macam pola pembagian peran pria dan wanita dalam keluarga melalui pola hubungan yang ada dalam keluarga, yaitu:

1. Struktur Komplementasi (sering disebut pola keluarga tradisoanal)

2. Struktur Simetris (Struktur keluarga modern) dan 


\section{Muassomah}

\section{Struktur Paralel}

Dalam keluarga yang berstruktur komplementer ada dua pihak yang menjalankan peran secara berbeda, masing-masing menekankan ketidaksamaan peran, yakni suami memegang kekuasaan dalam keluarga, sebagai pencari nafkah, dan sebagai pemimpin, sedangkan isteri berperan sebagai pengurus rumah tangga yang memelihara anak, mengurus rumah tangga, dan sebagai penguasa di rumah. Selanjutnya dinyatakan bahwa dengan struktur komplementer maka terjadi saling ketergantungan antara suami dan isteri dalam keluarga. Hal ini bisa menciptakan keharmonisan dalam keluarga.

Berbeda dengan keluarga yang berstruktur komplementer, keluarga yang berstruktur simetris suami dan isteri memiliki kekuasaan yang seimbang berdasarkan kontrak. Keduanya bebas dalam menentukan kemandiriannya, isteri dapat mengelola dalam managemen keuangan keluarga begitu juga dengan suami. Isteri bebas menentukan karier, begitu juga dengan suami. Struktur simetris ini cenderung tidak stabil, bahkan biasanya tidak tahan dalam menghadapi goncangan yang terjadi dalam keluarga. Jika terjadi konflik mereka cenderung menyelesaikan persoalanya sendiri-sendiri.

Keluarga yang berstruktur paralel, merupakan gabungan dari struktur komplementer dan struktur simetris. Dalam keluarga ini, suami dan isteri memiliki hubungan saling melengkapi (komplementer) akan tetapi dalam waktu yang sama mereka memiliki beberapa bagian dari perilaku kekeluargaan mereka yang mandiri, yang biasanya dilakukan melalui negoisasi.

\section{Peran Domestik dan Peran Publik dalam Keluarga}

Menurut teori Nature, bahwa wanita lebih berperan di bidang domestik yakni melahirkan anak dan menyusui serta membesarkan dalam lingkungan keluarga, memasak dan memberi perhatian kepada suami agar dapat terjalin hubungan rumah tangga yang harmonis, tentram dan sejahtera. Sedangkan laki-laki lebih berperan di publik yakni mencari nafkah untuk melindungi keluarganya. Pembagian ini didasarkan atas perbedaan seks yang diatur oleh alam, secara alamiah. Laki-laki diberi kekuatan otot untuk bekerja mencari nafkah, sedangkan wanita memiliki organ tubuh yang bisa mengandung dan melahirkan serta menyusui. Berdasarkan hal ini, maka sangat jelas bahwa wanita lebih berperan di domestik dan laki-laki lebih berperan di publik.

Teori fungsional juga berpandangan, bahwa wanita harus tinggal di 
dalam rumah tangga (domestik) dan laki-laki harus berperan di luar rumah (publik), karena hal ini merupakan pembagian yang paling baik dan berguna bagi keuntungan masyarakat secara keseluruan.

Guettel menjelaskan, bahwa pembagian peran berdasarkan seksual ini tidak bersifat eksploitatif, pembagian ini benar-benar harmonis. Tetapi setelah pekerjaan di luar rumah dapat dimanfaatkan untuk mengumpulkan materi;, pekerjaan dalam masyarakat menjadi lebih berarti dan akibatnya laki-laki menjadi lebih berkuasa. Kenyataan ini mendorong laki-laki lebih melanggengkan kekuasaannya.

Fenomena yang terjadi dalam masyarakat menunjukkan bahwa semakin bergesernya keluarga inti menjadi semakin berat tanggung jawab rumah tangga atas kegiatan-kegiatan kerumahtanggaannya, sistem sosial dan norma-norma yang dianut akan sangat menentukan sikap masyarakat terhadap wanita, baik sebagai anggota keluarga, maupun sebagai tenaga kerja.

Wanita yang terlibat dalam pasar kerja sering dijumpai di mana-mana, sebaliknya banyak juga dilihat laki-laki tidak hanya melakukan pekerjaan di lingkup publik. Seolah pemisahan pekerjaan begitu ketat dan kaku terjadi dalam masyarakat. Pada masyarakat kelas bawah misalnya, ayah melakukan pekerjaan-pekerjaan domestik yakni kegiatan mengasuh anak, membersihkan rumah, sementara sang isteri bekerja di lingkup publik yakni berjualan di pasar atau sebagai buruh. Ada masyarakat kelas menengah, sudah bukan merupakan hal yang asing lagi apabila suami berbelanja untuk keperluan rumah tangganya dan ikut serta menentukan menu makan guna disajikan bagi keluarganya, sementara isteri ada urusan keluar kota.

Perubahan-perubahan peran seperti ini, nampaknya sedikit demi sedikit akan mewarnai kehidupan keluarga dalam masyarakat, lebih-lebih pada dasa warsa terakhir ini tidak sedikit para isteri yang bekerja atau memilih menjadi wanita karier.

\section{Perubahan Sosial secara Umum}

Secara umum, perubahan sosial bisa diartikan sebagai perubahan mendasar dalam pola budaya, struktur dan perilaku sosial sepanjang waktu sebagai perubahan sosial. Perubahan sosial pada dasarnya merupakan proses yang dilalui masyarakat sehingga menjadi berbeda dengan sebelumnya.

William E. Moore Ogburn berusaha memberikan sesuatu pengertian tertentu walau tidak memberi definisi tentang perubahan-perubahan sosial. 
Dia mengemukakan ruang lingkup perubahan-perubahan sosial meliputi unsur-unsur kebudayaan baik yang material maupun yang immaterial, yang ditekankan adalah pengaruh besar unsur-unsur kebudayaan material terhadap kebudayaan immaterial. Kingsley David mengartikan perubahan sosial sebagai perubahanperubahan yang terjadi dalam struktur dan fungsi masyarakat. Misalnya, timbulnya pengorganisasian buruh dalam masyarakat kapitalis telah menyebabkan perubahan-perubahan dalam hubungan antara buruh dengan majikan dan seterusnya menyebabkan perubahan-perubahan dalam organisasi ekonomi dan politik.

Gillin dan Gillin mengatakan perubahan-perubahan sosial sebagai suatu variasi dari cara-cara hidup yang sudah diterima, baik karena perubahanperubahan kondisi geografis, kebudayaan material, komposisi penduduk, ideologi maupun karena adanya difusi ataupun penemuan-penemuan baru dalam masyarakat. Secara singkat Samuel Koenig mengatakan bahwa perubahan sosial menunjuk pada modifikasi-modifikasi yang terjadi dalam pola-pola kehidupan manusia. Modifikasi-modifikasi mana terjadi karena sebab-sebab intern maupun sebab-sebab ekstern.

Gejala pokok perubahan sosial adalah perbedaan pola budaya, struktur dan perilaku sosial antara satu waktu dengan waktu yang lain. Karena itu, perubahan sosial hanya dapat ditemukan setelah membandingkan antara pola budaya, perilaku dan struktur sosial pada waktu sebelumnya dengan pola budaya, perilaku dan struktur sosial sekarang. Semakin besar perbedaan, mencerminkan semakin luas dan mendalamnya suatu perubahan sosial.

Karena perubahan sosial memiliki cakupan sangat luas dan bertumpang tindih dengan perubahan budaya. Untuk analisis yang lebih tajam, para ilmuan membedakan perubahan dalam masyarakat menjadi tiga jenis, yaitu: (1) perubahan peradaban, (2) perubahan budaya, (3) perubahan sosial.

Perubahan peradaban biasanya dikaitkan dengan perubahan unsurunsur atau aspek yang lebih bersifat fisik, seperti sarana komunikasitransportasi, mesin-mesin dan sebagainya yang berjalan cepat. Menurut Koentjoriningrat (1958), segala sesuatu yang memiliki wujud fisik, akan lebih cepat berubah. Model pakaian, bangunan rumah, mobil, sepeda motor dan sebagainya, merupakan unsur-unsur peradaban yang mengalami perubahan sangat pesat. Karena itu, dalam perubahan peradaban berlaku kaidah kewujudan (physicality).

Perubahan budaya menyangkut aspek rohaniah, seperti keyakinan, nilai-nilai, pengetahuan, dan penghayatan seni, norma hubungan antara 
anak dengan orang tua, antara peserta didik dengan pendidik, antara bawahan dengan atasan, dan sejenisnya merupakan aspek rohaniah kebudayaan. Norma-norma ini, meskipun mengalami perubahan, namun tidak bisa secepat barang-barang peradaban.

Perubahan sosial menunjuk pada aspek-aspek hubungan sosial, pranata-pranata masyarakat, dan pola prilaku kelompok. Salah satu contoh perubahan sosial adalah semakin banyaknya pranata-pranata masyarakat yang baersifat formal. Misalnya berbagai organisasi, mulai dari organisasi pemerintahan, hingga organisasi arisan, sekarang sudah semakin formal, dengan pola hubungan yang lebih rasional. Ini berbeda dengan organisasi sosial pada masyarakat jaman dahulu, yang lebih bersifat informal dengan pola hubungan emosional.

\section{Pengaruh Industrialisasi terhadap Perubahan Struktur Keluarga}

Menurut Ronalt Lippit yang dikutip oleh Merrill \& Elliot bahwa pendorong bagi perubahan keluarga adalah : berkembangnya kebudayaan materi, tingkat penemuan dan inovasi teknologi, perbaikan fasilitas transportasi dan komunikasi dan meluasnya Industrialisasi dan urbanisai. Dengan adanya perubahan-perubahan ini, masalah-masalah yang paling umum yang kita jumpai adalah terjadinya perkembangan-perkembangan dalam masyarakat, yang salah satunya adalah perubahan masyarakat dari masyarakat agraris yang tradisional ke masyarakat yang modern. Konsekwensi dari perubahan ini selanjutnya adalah pengaruh terhadap organisasi keluarga yakni perubahan dari extended family menjadi nuclear family. Ada 3 alasan yang menyebabkan perubahan tersebut:

1. Industrialisasi menyebabkan nuclear family menjadi lebih bersifat mobil, mudah berpindah dari satu tempat ke tempat yang lain. Keluarga tidak lagi terikat oleh sebidang tanah untk penghidupannya, melainkan mereka berpindah ke tempat di mana ada pekerjaan. Mobilitas keluarga ini akan memperlemah ikatan kekerabatan dalam extended family.

2. Industrialisasi dapat mempercepat emansipasi wanita, karena memungkinkan wanita untuk mendapatkan pekerjaan di luar rumah tangga. Emansipasi ini menyebabkan lemahnya fungsi-fungsi extended family di satu pihak, dan memperkuat nuclear family di pihak yang lain.

3. Industrialisasi telah menimbulkan corak kehidupan ekonomi baru dalam masyarakat. Dalam masyarakat agraria, semua anggota keluarga, anak-anak, wanita, orang sudah tua dapat turut serta dalam produksi pertanian, extended family memberikan keuntungan ekonomi. Dalam 


\section{Muassomah}

masyarakat industri: anak-anak, orang yang sudah tua, orang yang cacat tubuh, tidak dapat turut serta dalam proses produksi di pabrik, mereka menjadi beban keluarga.

\section{Pengaruh Migrasi Desa ke Kota terhadap Perubahan ekonomi kelu- arga}

Keputusan melakukan migrasi, menurut pendekatan Teori The Behavioural Approach seperti yang dikemukakan oleh Julian Walpert (1965), perpindahan penduduk adalah akibat dari keputusan seseorang atau kelompok yang memperkirakan bahwa total manfaat dari melakukan migrasi akan lebih besar dari pada biaya yang harus dikeluarkan dan manfaat yang hilang pada lokasi lain. Sedangkan menurut Hugo (1978) perpindahan adalah bukti terhadap tekanan baik secara fisik, ekonomi, sosial dan lingkungan budaya yang dirasakan oleh sesorang. Dan menurut Mantra (1981) setiap individu mempuntyai keinginan tertentu yang harus direalisasikan. Apabila keinginan dan aspirasi tersebut tidak bisa dipenuhi di tempat asal, maka muncul tekanan untuk bermigrasi.

Teori pembangunan dari Lewis, memandang migrasi dari desa ke kota sebagai sesuatu yang baik. Migrasi intern dianggap sebagai proses alami di mana surplus tenaga kerja sedikit demi sedikit ditarik dari sektor pedesaan untuk memenuhi tenaga kerja yang dibutuhkan dalam pertumbuhan daerah perkotaan. Secara sosial proses tersebut dianggap menguntungkan karena sumber daya manusia, berpindah dari tempat yang produk marjinalnya secara sosial (Marginal Product) diasumsikan nol ke tempat yang produk marjinalnya bukan hanya positif tetapi juga terus tumbuh secara cepat berkat adanya akumulasi kapital dan kemajuan teknologi.

Berkenaan dengan dampak migrasi terhadap perubahan sosial, penelitian Saefullah menemukan bahwa remitan dari kaum migran sangat berpengaruh terhadap peningkatan pendapatan dan perbaikan ekonomi rumah tangga penduduk desa pelaku migrasi, dalam pengertian remitan termasuk berbagai macam pelibatan yang diberikan pelaku migrasi kepada keluarga, saudara, ataupun sumbangan terhadap penduduk dan pembangunan desa. Karena remitan para migran cukup besar dan sangat menentukan tingkat kesejahteraan suatu rumah tangga, maka migrasi dinilai mempunyai peranan yang cukup besar di dalam mengubah kehidupan ekonomi daerah pedesaan.

Menurut Naim (1984), migrasi mempengaruhi daerah pengiriman dan daerah penerimaan secara demografis, jumlah, golongan umur dan 
komposisi seks. Mereka yang pergi cenderung pada usia kerja dan lebih banyak laki-laki. Kenyataan ini mempengaruhi kehidupan ekonomi secara berarti, dilihat dari ketenagakerjaan dan arus uang yang terjadi, secara sosiologis dampaknya dapat dilihat pada kehidupan sosial di daerah pengiriman dan daerah penerimaan. Sejalan dengan itu terjadi arus informasi yang intensitasnya berkorelasi dengan arus migrasi tersebut.

Dari penelitian tentang perantauan di kalangan orang Minangkabau, misalnya, Naim menyimpulkan bahwa dari segi ekonomi, merantau memperlihatkan efek positif dan sekaligus negatif. Dengan tingginya tingkat merantau, mereka yang tinggal di Sumatera Barat mendapat pertolongan dan bisa merasa lega, sementara mereka yang pergi merantau menemukan kesempatan yang lebih baik untuk penghidupan, karier, ataupun pengalaman, karena itu, bagi banyak orang Sumatera Barat, hanya dengan merantau mereka dapat membantu sanak keluarga mereka di kampung halaman, baik dalam bentuk keuangan maupun yang lain.

Walaupun demikian, secara bersamaan merantau juga menyebabkan pelarian tenaga kerja dan tenaga terdidik, baik dari daerah pedesaan maupun dari daerah perkotaan, dan merantau berarti telah menghalangi pertumbuhan kota. Prospek masa depan pertumbuhan ekonomi di Sumatra Barat, sekurangnya sejauh yang menyangkut dengan masalah tenaga kerja dan tenaga terdidik juga akan langsung dipengaruhi.

Penelitian mengenai dampak mobilitas penduduk terhadap perubahan sosial di pedesaan juga dilakukan oleh Saefullah. Dari penelitian ini, tampat kecenderungan bahwa kepergian orang desa ke kota telah membuat masyarakat desa berfikir luas, bersikap progresif dan terbuka terhadap perubahan. Walaupun demikian, kecenderungan ini disertai perubahan sikap masyarakat pedesaan, dari rasa sosial yang tinggi menjadi sikap komersial, konsumtif dan materialistis. Dari segi ekonomi, mereka yang melakukan mobilitas mengatakan bahwa kehidupan ekonomi rumah tangganya menjadi lebih baik setelah mereka bekerja di luar desa. Pelaku mobilitas juga menjadi penghubung antara kehidupan kota yang modern dengan kehidupan desa tradisional. Karena itu, bisa dikemukakan bahwa pelaku migrasi telah menjadi sumber informasi kemajuan dan kehidupan dunia luar serta menjadi modal manusia modern di desa.

\section{Kesimpulan}

Berdasarkan hasil penelitian tentang Domestikasi Peran Suami dalam Keluarga, bisa ditarik kesimpulan sebagai berikut: 


\section{Muassomah}

1. Adapun faktor yang menyebabkan terjadinya perubahan peran suami dari peran publik ke peran domestik adalah karena faktor ekonomi. Semakin hari tuntutan kebutuhan hidup dalam keluarga pedagang ini semakin meningkat, sementara penghasilan suami dirasa tidak cukup untuk memenuhi kebutuhan keluarga tersebut, sehingga isteri termotivasi untuk bekerja di luar rumah untuk mencari nafkah tambahan. Tuntutan hidup mereka semakin tinggi karena semakin hari anak-anak mereka semakin tumbuh dewasa, ditambah lagi dengan gaya hidup mereka yang mulai terpengaruh dengan gaya hidup modern. Gaya hidup mereka yang modern ini bisa dilihat dalam kehidupan mereka sehari-hari, dari cara mereka mengkonsumsi kebutuhan sehari-hari, juga bisa dilihat dari perabot rumah tangga yang telah mereka beli, dan lain-lain.

2. Perubahan peran ini terjadi karena karena adanya pembagian kerja yang sudah disepakati antara pihak suami dan pihak isteri. Yakni isteri yang pergi ke luar rumah untuk mencari nafkah sedangkan suami yang mengurus rumah.

3. Terjadinya pergeseran nilai-nilai budaya karena pergeseran ekonomi.

\section{DAFTAR PUSTAKA}

Saefullah, A.D. Juli 1994. Sisi Positif Negatif Migrasi, Studi Kasus di Jawa Barat. Prisma. Tahun XXIII, Nomor 7.

Budiman, Arif. 1985. Pembagian Kerja Secara Seksual. Jakarta: Gramedia.

Rahmat, Djalaluddin.1992. Keluarga Muslim. Bandung: Keluarga Resdakarya.

Johnson, Doyle Paul. 1986. Teori Sosiologi. Jakarta: PT Gramedia Pustaka Utama.

Mantra, Ida Bagus. 1985. Pengantar Studi Demografi. Jakarta: Penerbit Nur Cahya.

Vander Zanden, James W. 1990. Sosiologi: The Core. New York: Mc Graw- 
Hill Publishing Campany.

Kartono, Kartini. 1986. Psikologi Wanita (Gadis Remaja \& Wanita Dewasa). Bandung: Alumni.

Khairuddin, H. SS. 2002. Sosiologi Keluarga. Yogyakarta: Liberty.

Koentjaraningrat. 1988. Metode-metode Antropologi dalam Penyelidikanpenyelidikan Masyrakat dan Kebudayaan di Indonesia. Jakarta: Penerbitan Universitas.

Amin, M. Masyhur \& Masruchan, (eds). 1992. Wanita dalam Percakapan antara Agama. Yogyakarta: LKPSM.

Todaro, Michael P. 1993. Pembangunan Ekonomi di Dunia ke III. (eds). III, jilid I. Jakarta: Penerbit Erlangga.

Naim, Mochtar. 1984. Merantau : Pola Migrasi Suku Minangkabau. Yogyakarta: UGM Press.

Sajogjo \& Sajogjo, Pudjiawati. 1989. Sosiologi Pedesaan. Yogyakarta: Gajahmada University Press.

Kanto, Sanggar. 1998. Mobilitas Tenaga Kerja dari Desa ke Kota. Ringkasan Desertasi Program Pascasarjana Universitas Airlangga. Surabaya: Universitas Airlangga.

Selosoemardjan. 1962. Social Changes in Jogjakarta. Yogyakarta: UGM 